\title{
Evaluation of Hinguleshwara Rasa by ICP AES Elemental Qualitative Analysis for Standardization
}

\author{
Research Article
}

\section{Ajay Bapusaheb Sonawane ${ }^{*}$, Archana P Gharote ${ }^{2}$}

\begin{abstract}
1. Ph.D (Scholar), 2. Professor, Department of Rasashastra and Bhaishajya Kalpana School of Ayurveda, D Y Patil deemed to be University, Navi Mumbai. India.
\end{abstract}

\begin{abstract}
In Ayurveda Shodhan (purification) process plays a very significant role in purification of Herbal \& Mineral drugs like Hingul (Cinnabar) \& Vatsanabh (Aconitum ferox) for internal administration. Hinguleshwar rasa is one of the important Herbo-mineral formulation in Ayurveda. In this study we performed purification (shodhan) of Hingul (cinnabar) \& Vatsanabh (Aconitum ferox) according to text and after using it in Hinguleshwar rasa we try to find out elemental changes during whole purification \& trituration process. Because of the need of purification \& standardisation in Ayurveda we do ICP AES Elemental qualitative analysis of drug and formulation. After doing ICP AES test of purified Hingul we found elements like Chromium, Sodium, Tungsten. but these element were not present in sample of raw Hingul (Cinnabar). In the sample of purified and un-purified Vatsanabh (Aconitum ferox) we not found any significant different element in this test. In Hinguleshwar rasa we not found elements which are present in purified Hingul (Cinnabar) \& purified Vatsanabh (Aconitum ferox) like Chromium, Gallium, Nickel and Tungsten. Hence this study concludes that some elemental changes may happen after purification, trituration process and during preparation of any formulation. ICP AES elemental qualitative analysis helps to find out elemental changes in the given sample.
\end{abstract}

Key Words: Hingul, Vatsanabh, Hinguleshwar rasa, Pippali, ICP-AES.

\section{Introduction}

In Ayurveda many Herbo-mineral formulation was mentioned in texts of Rasashastra. Hinguleshwar rasa and its contents like shodhit (purified) Hingul (Cinnabar), Vatsanabh (Aconitum ferox) \& Pippali (Piper longum L.) were used in different disease. Standardization of herbo-mineral formulation on the elemental level is a need of present era. ICP AES Elemental qualitative analysis of Hinguleshwar rasa, Pippali (Piper longum), shodhit Ashodhit Hingul (Cinnabar) and Vatsanabh (Aconitum ferox) were carried out in IIT Bombay for find out elemental changes after purification \& during preparation process of formulation.

ICP AES was use for Precious metal estimation at low level, Heavy metal estimation at sub ppm level and in pharmaceutical industries(1). ICPAES study reveals various elements in the Hinguleshwar rasa and in Hingul before and after the purification process. In this present study ICP AES Elemental qualitative analysis helps to evaluate \& standardize the process of Hinguleshwar rasa \& its contents.

* Corresponding Author:

Ajay Bapusaheb Sonawane

Lig 2,f 24, sector 1 ,

kalamboli cidco colony,

Taluka Panvel, District Raigad,

Maharashtra. 410218, India.

Email Id: drajaysonawane03@gmail.com

\section{Materials and methods}

Material and method of preparation of Hinguleshwar rasa:

Preparation process of Hinguleshwar rasa was carried out at Department of Rasashastra and Bhaishajya kalpana in school of Ayurveda, D Y Patil deemed to be University Nerul, Navi Mumbai.

Identification of Drug: on the basis of physical properties and botanical parameters.

\author{
Method \\ Hingul (cinnabar) Shodhan (purification) by kshalan \\ (washing) method $(2,5,6)$ \\ Equipment \\ - Khalva yantra (Mortar and pestle) \\ - Measuring cylinder \\ - Glass jar \\ Ingredients \\ - Ashudha Hingul (Raw Cinnabar) \\ - Nimbuk (Lime, Citrus acida) (7) \\ - Deionized (DI) water \\ Procedure
}

Raw Hingul (Cinnabar) powder was triturated with Lemon juice for seven times (seven bhavana) in khalva yantra. After completion of seven times trituration, Hingul turns crystallised to powder form and its $\mathrm{pH}$ was highly acidic. Then do seven times kshalan (washing) with DI water of this triturated Hingul (Cinnabar). After kshalan, Hingul (Cinnabar) become a very smooth dark red in colour, lustreless and $\mathrm{pH}$ comes near the neutral. The process was completed in 14 days and the final 
Ajay Bapusaheb Sonawane et.al., Evaluation of Hinguleshwara Rasa by ICP AES Elemental Qualitative Analysis

product called shodhit (purified) Hingul (Cinnabar) obtained.

Vatsanabh (Aconitum ferox, monk's hood)(8) Shodhan (purification) in Gomutra(3,6) (Cow urine)

Equipment

- Vessel

Ingredients

- Small Pieces of Ashudha Vatsanabh (Aconitum ferox, monk's hood)

- Gomutra (Cow urine)

Procedure

- Small pieces of Ashudha (unpurified) Vatsanabh (Aconitum ferox,monk's hood) immersed in gomutra (Cow urine) in the vessel for 3 days in sunlight. Daily replace gomutra (Cow urine) with fresh gomutra (Cow urine). After three days remove outer covering of Vatsanabh (Aconitum ferox) and then dried it in sunlight

Preparation of Hinguleshwar Rasa according to the Rasatarangini.(4,6)

Equipment

- Vessel

- Spoon

- Weighing machine

- Stone grinder

Ingredients of Hinguleshwar rasa

- Purified (Shodhit) Hingul (Cinnabar) powder: 100gm

- Purified (Shodhit) Vatsanabh (Aconitum ferox,monk's hood) powder: 100gm

- Pippali (piper longum) churna (powder): 100g

Procedure

- Take equal amount of Shodhit (purified) Hingul (Cinnabar) powder, Shodhit (purified) Vatsanabh (Aconitum ferox) churna (powder) and Pippali churna (piper longum powder) in stone grinder. Then triturate it well till formation of uniform mixture.

\section{Images of Hinguleshwar rasa}

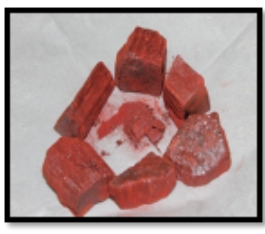

Fig.1. Unpurified Hingul

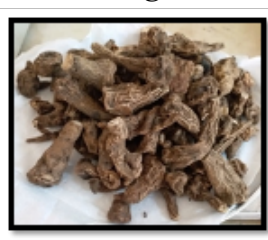

Fig.4. Unpurified Vatsanabh

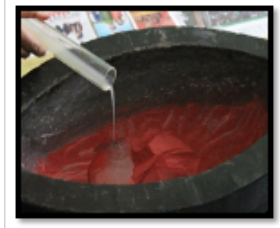

Fig.2. lemon juice and Hingul powder

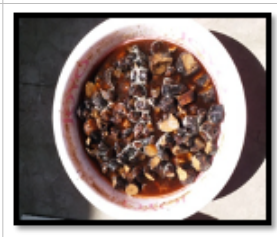

Fig.5. Vatsanabh shodhan in cow urine

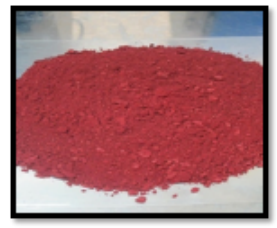

Fig.3. Purified Hingul powder

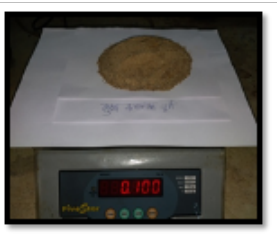

Fig.6. Purified Vatsanabh powder

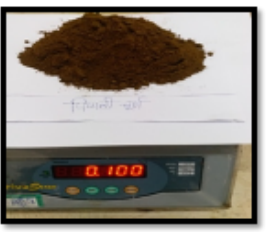

Fig.7. Pippali powder

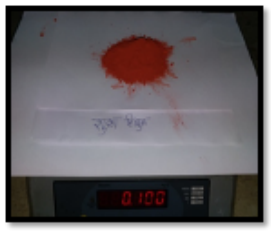

Fig.8. Purified Hingul

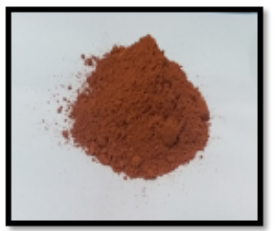

Fig.9.

Hinguleshwar rasa
Modern parameters for analysis of $\operatorname{drugs}(1)$ :

ICP AES test was performed in IIT Bombay for obtaining the elemental qualitative analysis.

Inductively Coupled Plasma-Atomic Emission Spectrometry (ICP- AES) is an emission spectrophotometric technique. In this test analyst can qualitatively and quantitatively find the elements from the given sample relative to a reference standard.

Procedure

- Sample was prepared in ANTON PARR MICROWAVE go system (Temperature $190^{\circ} \mathrm{c}$, RAMP 15)

- Taken $0.1 \mathrm{gm}$ of sample in to the digestion vessel $+5 \mathrm{ml}$ of concentrated $\mathrm{HNO}_{3}$

- Swirl the mixture \& hold for $25 \mathrm{~min}$.

- Final solution was made upto $50 \mathrm{ml}$ with distilled water.

- Then this prepared sample was introduced in ICPAES machine for analysis.

There are six samples for full scan

1. First sample: Raw Hingul (Cinnabar). (A)

2. Second sample: Shodhit (purified) Hingul (Cinnabar). (A1)

3. Third sample: Ashudha (unpurified) vatsanabh (Aconitum ferox) (B)

4. Fourth sample: Shodhit (purified) vatsanabh (Aconitum ferox) (B1)

5. Fifth sample: Pippali (Piper longum) (C)

6. Sixth sample: Hinguleshwar rasa (D)

Table 1

\begin{tabular}{|c|c|c|c|}
\hline $\begin{array}{l}\text { Sr. } \\
\text { no }\end{array}$ & $\begin{array}{l}\text { Name of the } \\
\text { sample }\end{array}$ & Detected elements & $\begin{array}{l}\text { Number of } \\
\text { detected } \\
\text { elements }\end{array}$ \\
\hline 1 & $\begin{array}{l}\text { Raw Hingul. } \\
\text { (A) }\end{array}$ & $\begin{array}{c}\mathrm{Ag}, \mathrm{Al}, \mathrm{As}, \mathrm{Ba}, \mathrm{Bi}, \mathrm{Ca}, \mathrm{Cu} \\
\mathrm{Fe}, \mathrm{Ga}, \mathrm{Hg}, \mathrm{Mg}, \mathrm{Mn}, \mathrm{Mo} \\
\text { Pb, S, Si, Sr, Ti, Zn }\end{array}$ & 19 \\
\hline 2 & $\begin{array}{c}\text { Shodhit } \\
\text { Hingul. (A1) }\end{array}$ & $\begin{array}{c}\mathrm{Al}, \mathrm{As}, \mathrm{Ba}, \mathrm{Bi}, \mathrm{Ca}, \mathrm{Cr}, \mathrm{Cu} \\
\mathrm{Fe}, \mathrm{Ga}, \mathrm{Hg}, \mathrm{Mg}, \mathrm{Mn}, \mathrm{Mo} \\
\mathrm{Na}, \mathrm{Pb}, \mathrm{S}, \mathrm{Si}, \mathrm{Sr}, \mathrm{Ti}, \mathrm{W}, \mathrm{Zn}\end{array}$ & 21 \\
\hline 3 & $\begin{array}{c}\text { Ashudha } \\
\text { vatsanabh (B) }\end{array}$ & $\begin{array}{c}\mathrm{Al}, \mathrm{B}, \mathrm{Ba}, \mathrm{Ca}, \mathrm{Cl}, \mathrm{Cu}, \mathrm{Fe} \\
\mathrm{Hg}, \mathrm{K}, \mathrm{Mg}, \mathrm{Mn}, \mathrm{Na}, \mathrm{Ni}, \mathrm{P}, \mathrm{S} \\
\text { Si, Sr, Ti, Zn }\end{array}$ & 19 \\
\hline 4 & $\begin{array}{l}\text { Shodhit } \\
\text { vatsanabh } \\
\text { (B1) }\end{array}$ & $\begin{array}{c}\text { Al, B, Ba, Ca, Cl, Cu, Fe, } \\
\mathrm{Hg}, \mathrm{K}, \mathrm{Mg}, \mathrm{Mn}, \mathrm{Na}, \mathrm{Ni}, \mathrm{P}, \mathrm{S} \\
\text { Si, Sr, Ti, Zn }\end{array}$ & 19 \\
\hline 5 & Pippali (C) & $\begin{array}{l}\mathrm{Al}, \mathrm{B}, \mathrm{Ba}, \mathrm{Ca}, \mathrm{Cl}, \mathrm{Cr}, \mathrm{Cu}, \mathrm{Fe} \\
\mathrm{Hg}, \mathrm{K}, \mathrm{Mg}, \mathrm{Mn}, \mathrm{Na}, \mathrm{P}, \mathrm{S}, \mathrm{Si} \\
\text { Sr, Ti, Zn }\end{array}$ & 19 \\
\hline 6 & $\begin{array}{l}\text { Hinguleshwar } \\
\text { rasa (D) }\end{array}$ & $\begin{array}{l}\mathrm{Al}, \mathrm{As}, \mathrm{B}, \mathrm{Ba}, \mathrm{Ca}, \mathrm{Cl}, \mathrm{Cu} \\
\mathrm{Fe}, \mathrm{Hg}, \mathrm{K}, \mathrm{Mg}, \mathrm{Mn}, \mathrm{Na}, \mathrm{P}, \mathrm{S} \\
\text { Si, Sr, Ti, Zn }\end{array}$ & 19 \\
\hline
\end{tabular}




\section{Observations \& Results}

In ICP AES qualitative analysis report found some element in the samples.

1.In the sample of shodhit Hingul (purified Cinnabar) we found elements like Chromium (CR), Sodium (NA), Tungsten (W). but these element were not present in sample of unpurified raw Hingul.

2.In the sample of shodhit and ashudha Vatsanabh (purified \& un-purified Aconitum ferox) we not found any different significant element in this test.

3.In sample of Hinguleshwar rasa we not found elements which are present in shodhit Hingul (purified Cinnabar) \& shodhit Vatsanabh (purified Aconitum ferox) like Chromium (CR), Gallium (GA), Molybdenum (MO), Nickel (NI), Lead (PB), Tungsten (W).

\section{Discussion}

ICP AES elemental qualitative analysis test used for standardization of drug on the elemental level. It helps to know the elemental changes after carried out different procedures which are mentioned in Ayurveda like Shodhan (purification), Mardan( trituration) etc. In this study ICP AES test of purified (shodhit) Hingul (Cinnabar) we found elements like Chromium (CR), Sodium (NA), Tungsten (W). but these element were not present in sample of raw Hingul. In the sample of purified (shodhit) and un-purified (Ashodhit) Vatsanabh (Aconitum ferox, monk's hood) we not found any different significant element in this test. In Hinguleshwar rasa we not found elements which are present in shodhit Hingul (purified Cinnabar) \& shodhit Vatsanabh (purified Aconitum ferox, monk's hood) like Chromium (CR), Gallium (GA), Molybdenum (MO), Nickel (NI), Lead (PB), Tungsten (W).. Hence we conclude that some elemental changes happened after purification and trituration process during preparation of any formulation.

\section{Conclusion}

Hence this study concluded that ICP AES elemental qualitative analysis test helps to standardized $\&$ find out elemental changes in the Hinguleshwar rasa and its contents. There is no significant specific element was found in the Hinguleshwar rasa.

\section{References}

1. http://www.saif.iitb.ac.in/icp-aes.html dated 22-09-2020 time 11:46.

2. Sadananda Sharma: Rasa tarangini, edited by Pt. Kashinath Shastry, 11th edition, 1979, published by Motilal Banarasidas, Varanasi. Tarang 9, Pg.no.202.

3. Sadananda Sharma: Rasa tarangini, edited by Pt. Kashinath Shastry, 11th edition, 1979, published by Motilal Banarasidas, Varanasi. Tarang 24, Pg.no.651.

4. Sadananda Sharma: Rasa tarangini, edited by Pt. Kashinath Shastry, 11th edition, 1979, published by Motilal Banarasidas, Varanasi. Tarang 24, Pg.no.662.

5. Sonawane Ajay Bapusaheb, Bhadlikar Devyani Deodatta, Mehta Mahendra Tryambaklal, Nilesh Suryavanshi2, Bhapkar Vedvati: To study the qualitative analysis and images of hingul during the shodhan process, International Journal of Ayurveda and Pharma Research 2015;3 (11) : 1-5.

6. Ajay Bapusaheb Sonawane, Archana P. Gharote: FEG-SEM, XRD \& HPTLC of shodhit ashodhit hingul, shodhit ashodhit vatsanabh \& hinguleshwar rasa for standardization, European journal of pharmaceutical and medical research, ejpmr, 2020,7(6), 515-518.

7. Vaidya Vishnu M Gogate, Dravyaguna Vigyan, $4^{\text {th }}$ edition 2017, published by Vaidymitra Prakashan,701, Sadashiv Peth, Pune. Pg.no.478.

8. Vaidya Vishnu M Gogate, Dravyaguna Vigyan, $4^{\text {th }}$ edition 2017, published by Vaidymitra Prakashan,701, Sadashiv Peth, Pune. Pg.no.614. 